\title{
Gambaran Penderita Filariasis di Kabupaten Meranti Provinsi Riau Periode 2009-2014
}

\author{
Esy Maryanti ${ }^{1 *}$, Andriyani ${ }^{2}$, Suyanto $^{3}$
}

\begin{abstract}
Filariasis is one of the health problems in Indonesia due to its long-term effect on permanent disability if not treated properly. The purpose of this study is to describe people with filariasis in Meranti District of Riau Province 2009-2014. The methods is a descriptive retrospective cross-sectional study using medical records of patients diagnosed with filariasis in hospitals and all health centers in the District of Meranti. The result showed 38 patients with filariasis, and the highest case of filariasis were in Puskesmas Pulau Merbau (94.8\%). Distribution by gender, age and type of occupation as follows: men by $71 \%, 86.8 \%$ of the subject belong to the age group 15-64 years old, and 65.8\% were outdoor workers, 52.6\% of lymphedema was reported and the location of lymphedema mostly found on each leg (18.4\%). All lymphedema were belong to all the stage not exceed stage III. All cases of filariasis in this study were managed according to the standard treatment.
\end{abstract}

Keywords: Tissue nematode, lymphedema, Riau Province.

Filariasis yang dikenal dengan penyakit kaki gajah atau elephantiasis adalah salah satu penyakit infeksi yang dapat menyerang semua golongan umur dan jenis kelamin. Filariasis ditularkan melalui gigitan nyamuk yang di dalam tubuhnya terdapat larva stadium III (bentuk infektif) dari cacing filaria, yaitu Wuchereria bancrofti, Brugia malayi dan Brugia timori. ${ }^{1}$ Cacing dewasa tersebut hidup di jaringan limfe sehingga dapat menyebabkan pembengkakan di ekstremitas, payudara dan organ genital. ${ }^{2}$ Filariasis bersifat kronis dan dapat menyebabkan kecacatan menetap bila tidak mendapatkan pengobatan, sehingga memberikan dampak psikologi, sosial budaya dan ekonomi yang cukup besar bagi penderita dan keluarganya. ${ }^{1}$ Estimasi kerugian negara akibat filariasis dapat mencapai 43 triliun rupiah per tahun jika program eliminasi filariasis tidak dilaksanakan. ${ }^{3}$

\footnotetext{
* Penulis untuk korespondensi : KJF Parasitologi Fakultas Kedokteran Universitas Riau, esy.maryanti@gmail.com

2. Mahasiswa Fakultas Kedokteran Universitas Riau

3. KJF IKM-IKK Fakultas Kedokteran Universitas Ria
}

Data World Health Organization (WHO) menunjukkan terdapat 1,3 miliar penduduk dunia yang tinggal di 73 negara berisiko tertular filariasis dan sebanyak $57 \%$ penderitanya berada di negaranegar Asia Tenggara, termasuk Indonesia. Berdasarkan data WHO tahun 2013, Indonesia menduduki peringkat ketiga sebagai negara endemis filariasis setelah India dan Nigeria. ${ }^{1}$ Indonesia juga merupakan satu-satunya negara di dunia yang memiliki ketiga jenis cacing penyebab filariasis. ${ }^{4}$

Departemen Kesehatan Republik Indonesia menyatakan jumlah kasus filariasisklinis di Indonesiaterus mengalami peningkatan, yaitu sebanyak 11.969 kasus pada tahun 2010 dan meningkat menjadi 12.714 kasus pada tahun 2013. Terdapat 302 kabupaten/kota endemis filariasis dari 497 kabupaten/kota di Indonesia pada tahun 2013 dengan kasus filariasis klinis tertinggi yaitu Daerah Istimewa Aceh sebanyak 2.359 kasus. Sementara Riau menempati urutan ke-10 dengan 310 kasus dari 33 provinsi yang terdapat di Indonesia. ${ }^{2.5}$

Kabupaten Meranti merupakan salah satu dari 12 kabupaten/kota yang terdapat di Provinsi Riau. Pembentukan Kabupaten Meranti merupakan hasil 
pemekaran dari Kabupaten Bengkalis pada tanggal 19 Desember 2008. ${ }^{6}$ Hasil survey parasitologis terhadap 12 kabupaten/kota di Provinsi Riau pada tahun 2012, Kabupaten Meranti memiliki nilai microfilaria rate ( $M f$ rate) tertinggi yaitu sebesar 2,4. Kabupaten Meranti juga memiliki kasus filariasis kronis tertinggi setelah Indragiri Hulu dan Indragiri Hilir pada tahun 2014. ${ }^{5}$ Karakteristik wilayah Kabupaten Meranti didominasi oleh rawarawa yang banyak ditumbuhi hutan bakau, ${ }^{6}$ sehingga merupakan daerah yang sangat potensial untuk perkembangbiakan vektor filariasis.

Tujuan penelitian ini adalah untuk mengetahui angka kejadian filariasis, distribusi penderita filariasis berdasarkan jenis kelamin, kelompok umur, pekerjaan, lokasi limfedema, stadium limfedema, spesies penyebab dan penatalaksanaandi Kabupaten Meranti Provinsi Riau periode 20092014.

\section{METODE}

Jenis penelitian ini menggunakan disain crosssectional deskriptif retrospektif dengan menggunakan data rekam medik pasien yang didiagnosis filariasis di RSUD Kabupaten
Kepulauan Meranti dan seluruh Puskesmas di Kabupaten Meranti periode 2009-2014.

Populasi dari penelitian ini adalah semua pasien yang didiagnosis oleh dokter menderita filariasis di RSUD Kabupaten Kepulauan Meranti dan Puskesmas Kabupaten Meranti periode 20092014. Sampel penelitian ini adalah seluruh populasi penelitian (total sampling).

Data yang diambil pada penelitian ini berupa data sekunder yang berasal dari rekam medik pasien yang didiagnosis oleh dokter menderita filariasis di RSUD Kabupaten Kepulauan Meranti dan seluruh Puskesmas di Kabupaten Meranti periode 20092014.

Pada penelitian ini variabel penelitian yang diteliti adalah umur, jenis kelamin, pekerjaan, lokasi dan stadium limfedema, spesies penyebab dan penatalaksanaan pada penderita filariasis.

\section{HASIL}

\section{Angka kejadian filariasis di Kabupaten Meranti periode 2009-2014}

Hasil pengambilan data sekunder terhadap 38 sampel didapatkan angka kejadian filariasis yang dapat dilihat pada tabel 1 .

Tabel 1 Angka kejadian filariasis berdasarkan asal fasilitas kesehatan $(\mathrm{N}=38)$

\begin{tabular}{lcc}
\hline \multicolumn{1}{c}{ Lokasi Penelitian } & N & \% \\
\hline - RSUD Kabupaten Kepulauan Meranti & - & - \\
- Puskesmas Selatpanjang & & - \\
- Puskesmas Alah Air & - & 2,6 \\
- Puskesmas Alai & - & - \\
- Puskesmas Kedapu Rapat & - & - \\
- Puskesmas Tanjung Samak & - & - \\
- Puskesmas Anak Setatah & - & - \\
- Puskesmas Teluk Belitung & 36 & 94,8 \\
- Puskesmas Pulau Merbau & 1 & 2,6 \\
- Puskesmas Bandul Jumlah & 38 & 100 \\
\hline
\end{tabular}


Berdasarkan tabel 1 dapat diketahui bahwa angka kejadian filariasis tertinggi terdapat di Puskesmas Pulau Merbau yaitu sebesar 94,8\% (36 orang).

\section{Distribusi penderita filariasis berdasarkan jenis kelamin, umur dan pekerjaan}

Berikut dipaparkan mengenai karakteristik demografi subyek penelitiana yaitu distribusi penderita filariasis berdasarkan jenis kelamin, kelompok umur dan tipe pekerjaan, yang dapat dilihat pada tabel 2 .

Tabel 2 Distribusi penderita filariasis berdasarkan jenis kelamin, umur dan pekerjaan

\begin{tabular}{ccc}
\hline \multicolumn{1}{c}{ Variabel } & N & \% \\
\hline Jenis Kelamin & & \\
$\bullet \quad$ Laki-laki & 27 & $\mathbf{7 1}$ \\
$\bullet \quad$ Perempuan & 11 & 29 \\
Kelompok Umur & & \\
$\bullet \quad<15$ tahun (usia muda) & - & - \\
$\bullet \quad 15-64$ tahun (usia produktif) & 33 & $\mathbf{8 6 , 8}$ \\
$\bullet \quad \geq 65$ tahun (usia non produktif) & 5 & 13,2 \\
Pekerjaan & & \\
$\bullet \quad$ Di luar ruangan & 25 & $\mathbf{6 5 , 8}$ \\
$\bullet \quad$ Di dalam ruangan & 13 & 34,2 \\
\hline
\end{tabular}

Berdasarkan tabel 2 dapat dilihat distribusikejadian filariasis lebih banyak ditemukan pada laki-laki daripada perempuan, yaitu 27 orang (71\%). Berdasarkan kelompok umur, penderita filariasis terbanyak terdapat pada kelompok umur 15-64 tahun sebesar $86,8 \%$ yaitu 33 orang, sedangkan untuk kelompok umur di bawah 15 tahun tidak ditemukan kejadian filariasis. Sementara itu, berdasarkan pekerjaan didapatkan bahwa kejadian filariasis terbanyak ditemukan pada jenis pekerjaan yang berada di luar ruangan sebesar $65,8 \%$ yaitu 25 orang.

\section{Distribusi penderita filariasis berdasarkan lokasi dan stadium limfedema}

Distribusi penderita filariasis berdasarkan lokasi dan stadium limfedema dapat dilihat pada tabel 3 .

Tabel 3 Distribusi penderita filariasis berdasarkan lokasi dan stadium limfedema

\begin{tabular}{|c|c|c|}
\hline Variabel & $\mathbf{N}$ & $\%$ \\
\hline \multicolumn{3}{|l|}{ Lokasi limfedema } \\
\hline - $\quad$ Belum menimbulkan limfedema & 18 & 47,4 \\
\hline - Tungkai & 20 & 52,6 \\
\hline - Lengan & - & - \\
\hline - $\quad$ Payudara & - & - \\
\hline - Alat kelamin & - & - \\
\hline \multicolumn{3}{|l|}{ Stadium limfedema } \\
\hline - $\quad$ Stadium 0 (belum menimbulkan limfedema) & 18 & 47,4 \\
\hline - $\quad$ Stadium I & 7 & 18,4 \\
\hline - $\quad$ Stadium II & 7 & 18,4 \\
\hline - $\quad$ Stadium III & 6 & 15,8 \\
\hline - $\quad$ Stadium IV & - & - \\
\hline - $\quad$ Stadium V & - & - \\
\hline - $\quad$ Stadium VI & - & - \\
\hline - $\quad$ Stadium VII & - & - \\
\hline
\end{tabular}


Berdasarkan tabel 3 dapat dilihat distribusi filariasis berdasarkan lokasi limfedema banyak ditemukan di bagian tungkai sebesar 52,6\%, jumlah tersebut tidak jauh berbeda dengan kejadian filariasis yang belum menimbulkan limfedema $(47,4 \%)$. Sementara pada lengan, payudara dan alat kelamin tidak ditemukan limfedema. Stadium limfedema penderita filariasis di atas stadium III tidak ditemukan.

\section{Distribusi penderita filariasis berdasarkan spesies penyebab}

Distribusi penderita filariasis berdasarkan spesies penyebab dapat dilihat pada tabel 4 .

Tabel 4 Distribusi penderita filariasis berdasarkan spesies penyebab

\begin{tabular}{llcc}
\hline & Spesies penyebab & $\mathbf{N}$ & $\%$ \\
\hline$\bullet$ & W. bancrofti & 2 & 5,3 \\
$\bullet$ & B. malayi & 15 & 39,5 \\
$\bullet$ & B. Timori & - & - \\
$\bullet$ & W. bancrofti dan B. Malayi & 1 & 2,6 \\
$\bullet$ & Negatif* & 20 & 52,6 \\
\hline
\end{tabular}

* Spesies penyebab negatif ditemukan pada kasus filariasis kronis

Berdasarkan tabel 4 didapatkan sebanyak $52,6 \%$ tidak ditemukan spesies penyebab filariasis. Brugia malayi merupakan spesies yang terbanyak ditemukan $(39,5 \%)$

\section{Distribusi penderita filariasis berdasarkan penatalaksanaan}

Distribusi penderita filariasis berdasarkan penatalaksanaan dapat dilihat pada tabel 5 .

Tabel 5 Distribusi penderita filariasis berdasarkan penatalaksanaan

\begin{tabular}{|c|c|c|}
\hline Jenis Kelamin & $\mathbf{N}$ & $\%$ \\
\hline $\begin{array}{l}\text { - Tidak sesuai dengan standar pengobatan } \\
\text { menurutKeputusan Menkes RI tahun } 2005\end{array}$ & - & - \\
\hline $\begin{array}{l}\text { - Sesuai dengan standar pengobatan menurutKeputusan } \\
\text { Menkes RI tahun } 2005\end{array}$ & 38 & 100 \\
\hline $\begin{array}{l}\text { - Sesuai dengan standar pengobatan menurut Keputusan } \\
\text { Menkes RI tahun } 2005 \text { dan operatif }\end{array}$ & - & - \\
\hline - Tidak diobati & - & - \\
\hline
\end{tabular}

Berdasarkan tabel 5 didapatkan bahwa semua kasus filariasis ditatalaksana sesuai dengan standar pengobatan menurut Keputusan Menkes RI tahun 2005, tidak ada kasus yang tidak diobati dan tidak ada tindakan operatif.

\section{PEMBAHASAN}

\section{Angka Kejadian Filariasis di Kabupaten Meranti Periode 2009-2014}

Angka kejadian filariasis pada penelitian ini sebanyak 38 orang. Angka kejadian filariasis tertinggi terdapat di Puskesmas Pulau Merbau yaitu sebesar 94,8\% (36 orang). Berdasarkan hasil observasi pada lokasi penelitian, Pulau Merbau merupakan daerah rawa-rawa dan banyak ditumbuhi hutan bakau yang cocok untuk perkembangbiakan vektor filariasis yaitu Anopheles barbirostris dan Mansonia uniformis. ${ }^{7}$

Sebagian besar penduduk di Kecamatan Pulau Merbau bekerja sebagai nelayan hingga malam hari dan biasanya tidak memakai pakaian lengkap saat berada di tengah sungai, sehingga berisiko tergigit vektor filariasis yang bersifat eksofagik yaitu 
Anopheles spp. dan Mansonia spp. Hal ini sesuai dengan penelitian Juriastuti $\mathrm{dkk}^{8}$ tentang faktor risiko kejadian filariasis di Kelurahan Jati Sampurna pada tahun 2010 yaitu responden yang memiliki kebiasaan berada di luar ruangan pada malam hari berisiko 5,4 kali lebih besar untuk terkena filariasis, karena suhu dan kelembaban udara yang dapat menambah aktivitas nyamuk menggigit manusia.

Penderita filariasis juga terdapat di Puskesmas Alah Air (1 orang) dan Puskesmas Bandul (1 orang) merupakan penduduk yang pindah dari Kecamatan Pulau Merbau dan menetap di Kecamatan Tebing Tinggi dan Kecamatan Tasik Putri Puyu. Pada puskesmas lainnya dan RSUD Kabupaten Kepulauan Meranti tidak terdapat penderita filariasis. Hal ini dapat disebabkan daerah selain Pulau Merbau bukan sebagai daerah transmigrasi penduduk. Selain itu, kemungkinan juga penderita filariasis yang terdapat di lokasi penelitian tidak melaporkan penyakit yang dialaminya ke puskesmas atau RSUD, sehingga kemungkinan menjadi missing case.

Angka kejadian filariasis di Kabupaten Meranti lebih rendah jika dibandingkan kejadian filariasis di Kabupaten Muaro Jambi pada tahun 2011, seperti yang dilaporkan oleh Santoso dkk sebanyak 149 orang. ${ }^{9}$ Demikian juga dengan angka kejadian filariasis di Kabupaten Sumba Barat Daya sebanyak 313 orang. ${ }^{10}$ Penemuan kasus filariasis di Kabupaten Meranti masih rendah kemungkinan disebabkan oleh masih sedikitnya pelaporan kasus filariasis ke fasilitas kesehatan.

\section{Distribusi Penderita Filariasis Berdasarkan Jenis Kelamin, Kelompok Umur dan Pekerjaan}

Hasil penelitian ini didapatkan $71 \%$ dari penderita filariasis berjenis kelamin laki-laki dan $29 \%$ adalah perempuan. Hasil ini sesuai dengan teori bahwa kejadian filariasis lebih tinggi pada laki-laki dibandingkan perempuan. ${ }^{11,12} \mathrm{Hal}$ ini tidak jauh berbeda dengan penelitian yang dilakukan Santoso $\mathrm{dkk}^{9}$ tentang faktor risiko filariasis di Kabupaten Muaro Jambi Provinsi Jambi pada tahun 2013 yaitu penderita filariasis berjenis kelamin laki-laki sebesar $80 \%$ dan perempuan sebesar 20\%. Penelitian Jontari $\mathrm{dkk}^{13}$ tentang faktor-faktor risiko kejadian limfatik filariasis di Kabupaten Agam Provinsi Sumatera Barat pada tahun 2014 menunjukkan kejadian filariasis pada laki-laki sebesar $64 \%$ dan perempuan sebesar $36 \%$. Penelitian Christian ${ }^{14}$ tentang perbandingan uji diagnostik dengan teknik pemeriksaan mikroskopik dan pemeriksaan serologi IgG4 pada populasi dewasa di Kabupaten Alor setelah pengobatan massal filariasis selama enam tahun pada tahun 2012 didapatkan 10,5\% laki-laki positif filariasis dibandingkan dengan $4,69 \%$ perempuan. ${ }^{14} \mathrm{Hal}$ ini terkait dengan aktivitas yang dilakukan oleh laki-laki sebagai pencari nafkah utama keluarga yang lebih banyak berada di luar rumah. Laki-laki juga memiliki mobilitas yang lebih tinggi dibandingkan perempuan sehingga risiko kontak dengan vektor lebih besar dibandingkan perempuan. Selain itu kejadian filariasis lebih banyak ditemukan pada laki-laki karena gejala penyakit ini lebih jelas dan nyata pada laki-laki diakibatkan pekerjaan fisik yang berat. ${ }^{11}$

Hasil penelitian berdasarkan kelompok umur didapatkan usia produktif (15-64 tahun) memiliki angka kejadian yang lebih tinggi dibandingkan kelompok usia lain yaitu sebesar $86,8 \%$ dan tidak ditemukan kejadian filariasis pada usia muda $(<15$ tahun). Hasil penelitiantersebut sesuai dengan teori yaitu kejadian filariasis paling banyak ditemukan pada kelompok umur dewasa muda (20-30 tahun) terutama penduduk dengan penghasilan rendah. ${ }^{10,17}$ Menurut penelitian yang dilakukan Juriastuti $\mathrm{dkk}^{11}$ tentang faktor risiko kejadian filariasis di Kelurahan Jati Sampurna Kota Bekasipada tahun 2010 menunjukkan penderita filariasis pada usia produktif lebih tinggi (71\%) dibandingkan usia non produktif (29\%). Sementara penelitian Sipayung $\mathrm{dkk}^{28}$ tentang pengaruh lingkungan biologi dan upaya pelayanan kesehatan terhadap kejadian filariasis limfatik di Kabupaten Sarmi Provinsi Papua pada tahun 2012 menunjukkan kelompok umur 20-49 tahun memiliki angka kejadian tertinggi yaitu sebesar $62,5 \%$. Hal ini dapat disebabkan pada usia muda dan usia non produktif tingkat penularan filariasis relatif rendah dan mikrofilaria tidak mudah terdeteksi. Penderita filariasis biasanya mengetahui penyakit yang dialaminya setelah timbul gejala kronis berupa pembengkakan di kaki maupun tangan. Selain itu, gejala filariasis biasanya muncul pada saat aktivitas berat yang biasanya dilakukan pada usia produktif.

Berdasarkan jenis pekerjaan, kejadian filariasis ditemukan terbanyak pada jenis pekerjaan yang berada di luar ruangan terutama nelayan yaitu 
sebesar $65,8 \%$. Sementara kejadian filariasis pada jenis pekerjaan yang berada di dalam ruangan sebesar 34,2\%. Hal ini sesuai teori bahwa penderita yang terkena filariasis kebanyakan ditemukan pada petani dan nelayan. ${ }^{15}$ Penelitian Sipayung $\mathrm{dkk}^{17}$ tentang pengaruh lingkungan biologi dan upaya pelayanan kesehatan terhadap kejadian filariasis limfatik di Kabupaten Sarmi Provinsi Papua pada tahun 2012 juga menunjukkan sebagian besar responden bekerja sebagai petani $47 \%$ dan nelayan $25 \%$ Hasil penelitian Sarungu dkk ${ }^{18}$ tentang faktor risiko lingkungan dan kebiasaan penduduk berhubungan dengan kejadian filariasis di Distrik Windesi Kabupaten Kepulauan Yapen Provinsi Papua pada tahun 2012 yaitu sebanyak 50\% penderita filariasis yang bekerja sebagai petani. Hal ini disebabkan karena vektor filariasis di lokasi penelitian bersifat eksofagik (Anopheles spp. dan Mansoniaspp.) sehingga pekerjaan yang berada di luar ruangan berisiko untuk tergigit vektor filariasis, terutama aktivitas di luar ruangan hingga malam hari yang tidak menggunakan pakaian lengkap dan tidak memakai repellent.

Hasil ini berbeda dengan penelitian Mardiana $\mathrm{dkk}^{19}$ tentang faktor-faktor yang mempengaruhi kejadian filariasis di Indonesia pada tahun 2011 bahwa pekerjaan tidak memiliki hubungan yang signifikan dengan kejadian filariasis. Hal ini dapat disebabkan oleh vektor filariasis yang bersifat endofagik seperti Culex spp. dan Aedes spp. sehingga pekerja yang berada di dalam ruangan juga berisiko terkena filariasis.

\section{Distribusi Penderita Filariasis Berdasarkan Lokasi dan Stadium Limfedema}

Penelitian ini menunjukkan lokasi limfedema paling banyak ditemukan di bagian tungkai terutama tungkai bawah dan kaki sebesar 52,6\%. Sementara pada bagian lengan, payudara dan alat kelamin tidak ditemukan tanda limfedema. Hal ini terkait kejadian filariasis di Kabupaten Meranti paling banyak disebabkan oleh Brugia malayi, patogenesis penyumbatan limfe pada jenis ini terbatas hanya sampai ekstremitas inferior bagian dista sehingga limfedema yang ditemukan juga hanya terbatas pada tungkai bawah dan kaki serta tidak mengenai lengan, payudara dan alat kelamin. Hal ini sesuai dengan teori bahwa limfedema pada filariasis malayi jarang terjadi pada lengan dan tidak menimbulkan pembengkakan pada payudara, saluran kemih serta kelamin. ${ }^{20}$ Limfedema pada filariasis malayi hanya mengenai tungkai bawah / di bawah lutut serta kadang-kadang mengenai lengan bawah / di bawah siku. ${ }^{12,15}$

Distribusi filariasis berdasarkan stadium limfedema terbanyak ditemukan pada stadium 0 (penderita yang belum mengalami limfedema) yaitu sebesar $47,4 \%$ (18 orang), kemungkinan hal itu terjadi karena ke-18 orang tersebut merupakan penderita filariasis baru sehingga belum menimbulkan gejala limfedema. Penderita filariasis dengan limfedema stadium I dan stadium II masingmasing ditemukan sebanyak $18,4 \%$ dan stadium III limfedema ditemukan pada 15,8\% kasus. Sebanyak 20 subjek penderita filariasis yang mengalami limfedema berbagai stadium merupakan kasus filariasis kronis ( 7 orang pada limfedema stadium I, 7 orang pada limfedema stadium II dan 6 orang pada limfedema stadium III). Penderita filariasis yang mengalami limfedema di atas stadium III tidak ditemukan karena kebanyakan kasus filariasis ditemukan setelah 1 tahun penderita mulai terinfeksi filariasis dan segera dilakukan tatalaksana oleh tenaga medis sehingga stadium limfedema pada penderita filariasis tidak bertambah parah ke stadium berikutnya. Hal ini juga sesuai teori bahwa penatalaksanaan filariasis yang sesuai standar pada stadium akut dan limfedema stadium I-II akan memberikan kesembuhan, ${ }^{16}$ sehingga penderita filariasis pada stadium III ke atas tidak ditemukan.

\section{Distribusi Penderita Filariasis Berdasarkan Spesies Penyebab}

Hasil penelitian ini didapatkan sebanyak 52,6\% tidak ditemukan spesies penyebab filariasis. Hal ini disebabkan kebanyakan penderita filariasis di Kabupaten Meranti adalah penderita kronis sehingga mikrofilaria tidak ditemukan di dalam darah. Hal ini sesuai teori bahwa pada stadium kronis, mikrofilaria sering tidak ditemukan lagi di dalam darah akibat obstruksi limfatik. ${ }^{16,20}$ Sementara itu filariasis yang disebabkan oleh Brugia malayi sebesar 39,5\% dan tidak ditemukan spesies penyebab Brugia timori. Filariasis yang disebabkan oleh infeksi campuran Wuchereria bancroftidan Brugia malayi hanya ditemukan 2,6\%. 
Hal ini sesuai dengan teori yaitu filariasis malayitersebar di daerah Sumatera, Kalimantan dan Sulawesi sedangkan filariasis timori terdapat di daerah Indonesia bagian timur. Sementara itu filariasis bankrofti pedesaan ditemukan terutama di Papua dan Nusa Tenggara. ${ }^{11} \mathrm{Hal}$ itu menjelaskan alasan sedikitnya jumlah filariasis yang disebabkan oleh Wuchereria bancrofti yang dapat ditemukan di lokasi penelitian. Hasil penelitian ini juga sesuai dengan penelitian Chadijah $\mathrm{dkk}^{21}$ tentang gambaran penularan filariasis di Provinsi Sulawesi Barat pada tahun 2014 yaitu Brugia malayi sebagaispesies terbanyak penyebab filariasis. Penelitian Santoso ${ }^{22}$ pada tahun 2014 tentangsituasi filariasis setelah pengobatan massal di Kabupaten Muaro Jambi didapatkan spesies penyebab filariasis terbanyak adalah Brugia malayi. Sementara itu penelitian Laumalay ${ }^{23}$ tentang kajian epidemiologi limfatik filariasis di Kabupaten Sumba Barat dan Sumba Tengah Provinsi Nusa Tenggara Timur pada tahun 2012 serta penelitian Maryen ${ }^{24}$ tentang faktor risiko yang berhubungan dengan kejadian filariasis di Kabupaten Manokwari Provinsi Papua Barat pada tahun 2014 ditemukan spesies terbanyak adalah Brugia timori.

\section{Distribusi Penderita Filariasis Berdasarkan Penatalaksanaan}

Berdasarkan penatalaksanaannya didapatkan bahwa semua kasus filariasis ditatalaksana sesuai dengan standar penatalaksanaan menurutKeputusan Menkes RI tahun 2005. Selain itu juga ditemukan fakta bahwa tidak ada kasus yang tidak diobati dan tidak ada tindakan operatif yang dilakukan untuk menangani komplikasi dari filariasis. Hal ini disebabkan Kabupaten Meranti merupakan daerah endemis filariasis sehingga program penataksanaan filariasis wajib diikuti oleh seluruh penduduk yang tinggal di daerah tersebut. Pengobatan filariasis juga diberikan secara gratis dan diawasi oleh petugas medis sehingga meningkatkan kepatuhan pasien dalam mejalankan pengobatan filariasis.

Tidak terdapatnya tindakan operatif pada penatalaksanaan filariasis di Kabupaten Meranti dapat disebabkan penderita filariasis pada Kabupaten Meranti menunjukkan perbaikan terhadap tatalaksana farmakologi yang adekuat. Hal ini sesuai dengan teori bahwa terapi bedah dipertimbangkan hanya apabila terapi farmakologis tidak memberikan hasil yang memuaskan. Tindakan operatif juga dilakukan pada penderita filariasis yang mengalami hidrokel besar yang tidak mengalami regresi spontan sesudah terapi farmakologi adekuat dengan tujuan drainase cairan untuk melancarkan aliran limfe. ${ }^{12}$

Adapun pengobatan filariasis sesuai standar berdasarkan Keputusan Menteri Kesehatan Nomor 1582 tahun 2005 tentang pedoman pengendalian filariasis yaitu diberikan DEC 3 x 1 tablet $100 \mathrm{mg}$ selama 10 hari berturut-turut dan parasetamol $3 \times 1$ tablet $500 \mathrm{mg}$ dalam 3 hari pertama untuk orang dewasa. Dosis anak-anak disesuaikan dengan berat badan. Penderita filariasis yang berada di daerah endemis pada tahun berikutnya diikutsertakan dalam pengobatan massal filariasis. ${ }^{25}$

\section{KESIMPULAN}

Kejadian filariasis di Kabupaten Meranti berjumlah 38 orang dan terbanyak terdapat di Puskesmas Pulau Merbau. Distribusi kejadian filariasis terbanyak pada laki-laki dengan kelompok umur 15-64 tahun (usia produktif) dan pada pekerja di luar ruangan. Distribusi kejadian filariasis berdasarkan lokasi dan stadium limfedema di bagian tungkai sebesar 52,6\%, masing-masing 18,4\% terdapat pada stadium I dan stadium II, 15,8\% pada stadium III dan tidak ditemukan limfedema di atas stadium III. Berdasarkan spesies penyebab, sebanyak 52,6\% tidak ditemukan spesies penyebab, 39,5\% disebabkan Brugia malayi, 5,3\% disebabkan Wuchereria bancrofti dan 2,6\% disebabkan campuran Brugia malayi dan Wuchereria bancrofti. Kasus filariasis ditatalaksana sesuai dengan standar pengobatan menurut Keputusan Menkes RI tahun 2005, tidak ada kasus yang tidak diobati dan tidak ada tindakan operatif.

\section{DAFTAR PUSTAKA}

1. World Health Organization. Lymphatic filariasis. [updated 2015; cited 2015 Jan 23]. Available from: http.www.who.int/media centre/ fasctsheets/fs 102/en.

2. Departemen Kesehatan RI. Profil kesehatan Indonesia 2013. 2014. [dikutip 25 Januari 2015]. 
Diakses dari: http://www.depkes.go.id/resources/ download/pusdatin/gambaran-kesehatanindonesia/gambaran-kesehatan-indonesia2013.pdf.

3. Departemen Kesehatan RI. Rencana nasional program akselerasi eliminasi filariasis di Indonesia tahun 2010-2014. Jakarta:Direktorat Jenderal PP \& PL,2010. [dikutip 25 Januari 2015]. Diakses dari: http://pppl.depkes.go.id/ _ a s s e t / _ d o w n l o a d / NATIONAL_PLAN_FILARIASIS_2010IND_2010-14.pdf

4. Departemen Kesehatan RI. Filariasis di Indonesia. Buletin jendela epidemiologi. 2010;1: 24. [dikutip 25 Januari 2015]. Diambil dari: http:/ / w w w . d e p k e s . g o . i d / download.php?file=download/pusdatin/buletin/ buletinfilariasis.pdf

5. Dinas Kesehatan Provinsi Riau. Profil kesehatan Provinsi Riau 2012-2014. Pekanbaru, 2015.

6. Pemerintah Kabupaten Meranti. Sejarah terbentuknya Kabupaten Meranti. 2011. [dikutip 26 Januari 2015]. Diambil dari: http:// merantikab.go.id/gambaran-meranti/html.

7. Oemijati S, Kurniawan A, Supali T. Epidemiologi filariasis. Dalam: Sutanto I, Ismid IS, Sjarifuddin PK, editors. Buku ajar parasitologi kedokteran. Edisi 4. Jakarta:Balai Penerbit Fakultas Kedokteran Universitas Indonesia;2008:40-2

8. Juriastuti P, Kartika M, Djaja IM dkk. Faktor risiko kejadian filariasis di Kelurahan Jati Sampurna. Jurnal Universitas Indonesia:Makara seri kesehatan. Juni 2010. [dikutip 23 Januari 2015];14(1):31-36. Diakses dari: http:// journal.ui.ac.id/health/article/download/645/ $\underline{630}$.

9. Santoso, Sitorus H, Oktarina R. Faktor risiko filariasis di Kabupaten Muaro Jambi. Buletin penelitian kesehatan. 2013. [dikutip 18 September 2015];41(2):152-152.Diakses dari: http://ejournal.litbang.depkes.go.id/.

10.Dinas Kesehatan Nusa Tenggara Timur. Profil kesehatan Nusa Tenggara Timur tahun 2012. 2013. [dikutip 9Oktober 2015]. Diakses dari: http://www.depkes.go.id/.
11.Oemijati S, Kurniawan A, Supali T. Epidemiologi filariasis. Dalam: Sutanto I, Ismid IS, Sjarifuddin PK, editors. Buku ajar parasitologi kedokteran. Edisi 4. Jakarta:Balai Penerbit Fakultas Kedokteran Universitas Indonesia;2008:40-2.

12.Pohan HT. Filariasis. Dalam: Sudoyo AW, Setiyohadi B, Alwi I, editors. Buku ajar ilmu penyakit dalam. Jilid 3 Edisi 5. Jakarta:Interna Publishing;2010:2931-7.

13.Jontari H, K Hari, Supargiyono dkk. Faktorfaktor risiko kejadian limfatik filariasis di Kabupaten Agam, Provinsi Sumatera Barat. Outbreaks, surveillance and investigation reports. March 2014. [dikutip 13 September 2015];7(1):9-15.Diakses dari: http:// www.osirjournal.net/.

14.Christian M. Uji diagnostik dengan teknik pemeriksaan mikroskopik dan pemeriksaan serologi IgG4 pada populasi dewasa di Kabupaten Alor setelah pengobatan massal filariasis selama enam tahun [skripsi]. Jakarta:Universitas Indonesia;2012.[dikutip 13September 2015]. Diakses dari: http:// lib.ui.ac.id/file?file=digital/20345246-SPDFMichael\%20Christian.pdf

15.Partono F, Kurniawan A, Supali T. Brugia malayi dan Brugia timori. Dalam: Sutanto I, Ismid IS, Sjarifuddin PK, editors. Buku ajar parasitologi kedokteran. Edisi 4. Jakarta:Balai Penerbit Fakultas Kedokteran Universitas Indonesia;2008:38-40.

16.Partono F, Kurniawan A, Supali T. Wuchereria bancrofti. Dalam: Sutanto I, Ismid IS, Sjarifuddin PK, editors. Buku ajar parasitologi kedokteran. Edisi 4. Jakarta: Balai Penerbit Fakultas Kedokteran Universitas Indonesia;2008:32-8.

17.Sipayung M, U Chatarina dkk. Pengaruh lingkungan biologi dan upaya pelayanan kesehatan terhadap kejadian filariasis limfatik di Kabupaten Sarmi. Jurnal berkala epidemiologi. Mei 2014. [dikutip 9 Oktober 2015];2(2):263-273.Diakses dari:http:// ejournal.litbang.depkes.go.id/.

18. Sarungu Y, Setiani O, Sulistiyani. Faktor risiko lingkungan dan kebiasaan penduduk berhubungan dengan kejadian filariasis di Distrik 
Windesi Kabupaten Kepulauan Yapen Provinsi Papua. Jurnal kesehatan lingkungan Indonesia. April 2012. [dikutip 9 Oktober 2015];11(1S):16.Diakses dari:http://ejournal.litbang. depkes.go.id/.

19. Mardiana, Lestari EW, Perwitasari D. Faktorfaktor yang mempengaruhi kejadian filariasis di Indonesia (data riskesdas 2007). Jurnal ekologi kesehatan. 2011. [dikutip 23 Januari 2015];10(2):83-92. Diakses dari: http:// ejournal.litbang.depkes.go.id/index.php/jek/ article/view/1699

20.Soedarto. Buku ajar parasitologi kedokteran. Jakarta:Sagung Seto;2011:221-7.

21.Chadijah S, Veridiana NN, Risti. Gambaran penularan filariasis di Provinsi Sulawesi Barat. Buletin penelitian kesehatan.2014. [dikutip 18 September 2015];42(2):101-107.Diakses dari:http://ejournal.litbang.depkes.go.id/.
22.Santoso, Taviv Y. Situasi filariasis setelah pengobatan massal di Kabupaten Muaro Jambi. Buletin penelitian kesehatan. September 2014. [dikutip 28 Oktober 2015];42(3):153160.Diakses dari: http://ejournal.litbang. depkes.go.id/.

23.Laumalay HM. Kajian epidemiologi limfatik filariasis di Kabupaten Sumba Barat (Desa Gaura) dan Sumba Tengah (Desa Ole Ate) tahun 2012. Jurnal penyakit bersumber binatang. Januari 2013. [dikutip 18 September 2015];22(1):16-24.Diakses dari:http://ejournal. litbang.depkes.go.id/.

24. Maryen Y. Faktor risiko yang berhubungan dengan kejadian filariasis di Kabupaten Manokwari Provinsi Papua Barat [tesis]. Yogyakarta:Universitas Gadjah Mada;2014. [dikutip 18September 2015]. Diakses dari: http:/ letd.repository.ugm.ac.id/

25.Keputusan Menteri Kesehatan Republik Indonesia Nomor 1582/Menkes/SK/XI/2005. Pedoman pengendalian filariasis (penyakit kaki gajah). 2005. 